\title{
Bone marrow in sickle cell anaemia at time of anaemic crisis
}

\author{
F K NKRUMAH, J E NEEQUAYE, AND G ANKRA-BADU \\ Departments of Child Health and Haematology, University of Ghana Medical School, Accra, Ghana
}

SUMmaRY Samples of bone marrow from 33 Ghanaian children with homozygous sickle cell anaemia who presented with profound anaemia (haemoglobin less than $5 \mathrm{~g} / \mathrm{dl}$ ) were studied. The principal finding was depression of erythropoiesis (aplastic crisis) in 14 children and erythroid hyperplasia in 17. A splenic sequestration crisis was clinically diagnosed in the remaining two children. Stainable iron was absent in the marrow of 14 children and reduced in another five. Megaloblastic changes compatible with folate deficiency were present in 8 children. It is suggested that iron and folate deficiencies may complicate sickle cell anaemia in children living in geographical areas where nutritional deficiencies are prevalent.

Sickle cell anaemia is one of the major hereditary health problems in tropical Africa where the sickle cell gene frequency is particularly high. The disease occurs with high incidence in west, east, and central Africa and this has been related to the prevalence of malaria in these regions. The classic hallmarks of sickle cell anaemia are reccurrent episodes of vasoocclusive crises often with multiorgan manifestations and a chronic haemolytic anaemia. Because of the hereditary nature of the disease patients with sickle cell anaemia are particularly symptomatic during childhood and in Africa many affected children do not survive to adulthood.

Most children with sickle cell anaemia maintain a haemoglobin concentration of between 7 and 8.5 $\mathrm{g} / \mathrm{dl}$ in the steady state. This is achieved through a fairly precise balance of accelerated rate of red blood cell destruction and a greatly increased marrow erythropoietic activity. Episodes of severe anaemia, which may be life threatening, do occur, however, particularly in children. These have been alluded to as haematologic or anaemic crises as distinct from vasoocclusive crises and are usually due to a temporary failure of bone marrow erythrocyte production (aplastic crisis), a splenic sequestration crisis, or a so called hyperhaemolytic crisis. The latter implies an enhanced destruction of sickle red blood cells beyond that which pertains in the steady state-that is, above the pre-crisis value. This is thought by many to occur rarely. ${ }^{1-3}$

Development of severe and often sudden anaemia requiring urgent transfusion occurs not infrequently in children with sickle cell anaemia attending the Paediatric Sickle Cell Clinic at the Korle Bu Teaching Hospital in Accra, Ghana. The present study was therefore undertaken to evaluate bone marrow erythropoiesis in a group of Ghanaian children with sickle cell anaemia who presented with severe, acute anaemia. We were particularly interested in documenting the frequency of aplastic crises in children from our geographical area and in evaluating marrow iron stores and changes that would suggest folate deficiency in these children.

\section{Patients and methods}

Children with homozygous sickle cell anaemia attending the Paediatric Sickle Cell Clinic at the Korle Bu Teaching Hospital, Accra, Ghana, who presented with severe anaemia were evaluated. Only those patients presenting with a haemoglobin concentration of less than $5 \mathrm{~g} / \mathrm{dl}$ were included in the study and were assessed by bone marrow examinations. All patients had required transfusion, many on emergency basis.

Bone marrow was aspirated from the upper third of the tibia in children aged less than 2 years and from the anterior or posterior iliac crest in older children. Multiple marrow smears were stained by May-Grünwald and Giemsa and for iron using Prussian blue stain counterstained with eosin. Only marrow smears with identifiable granules were included in the study. This necessitated the exclusion of four cases in which marrow smears were judged inadequate. Smears with adequate marrow were assessed for cellularity, myeloid:erythroid 
ratio, maturation of myeloid and erythroid series, megaloblastic changes, and iron stores. Megaloblastic changes were graded as mild, moderate, and considerable, and iron stores graded as adequate, increased, decreased, and absent.

Red cell glucose-6-phosphate dehydrogenase deficiency was screened for by the methaemoglobin reduction test in all patients and Giemsa stained thick blood films for malarial parasites were also examined in all children.

An attempt was made to document by history, examination, and investigations any antecedent or concomitant illnesses and associated vasoocclusive crisis, if any, on admission.

\section{Results}

Bone marrow aspirations from 33 children who presented with severe sickle cell anaemia (haemoglobin less than $5 \mathrm{~g} / \mathrm{dl}$ ) were evaluated. The children ranged in age from 5 months to 12 years: 18 were above 5 years of age and 6 were under 2 years of age. On the basis of marrow erythroid cellularity and the myeloid:erythroid ratios these children were subsequently categorised into two main groupsthose with marrow erythroid hypoplasia and those with erythroid hyperplasia.

Erythroid hypoplasia. (Aplastic crisis; Table 1). Depression of erythropoiesis was the main bone marrow finding in 14 of the 33 children. The depression of erythropoiesis was profound in 11 children and moderate in three. This corresponded with a myeloid:erythroid ratio ranging from $16: 1$ to 200:1 in those whose bone marrow was considered to show profound erythroid hypoplasia and 5:1 in the remaining three children who exhibited less severe hypoplasia. Haemoglobin concentrations in these 14 children with erythroid hypoplasia ranged from $2 \mathrm{~g} / \mathrm{dl}$ to $4.6 \mathrm{~g} / \mathrm{dl}$, with a mean of $3.1 \mathrm{~g} / \mathrm{dl}$.

Stainable iron was absent in the marrows of four of the 11 children with erythroid hypoplasia and was reduced in another three. Megaloblastic changes could not be assessed in this group of children since the degree of erythroid hypoplasia made such evaluation uncertain.

Erythroid hyperplasia. (Table 2). Erythroid hyperplasia was the major finding of marrow examination in 17 children. Myeloid:erythroid ratios ranged from $1: 1$ to $1: 3.5$ in these children and the mean haemoglobin concentration on admission was $4 \mathrm{~g} / \mathrm{dl}$, ranging from 2.8 to $4.9 \mathrm{~g} / \mathrm{dl}$. Stainable iron was absent in the marrows of 10 of the 17 children and was reduced in two. One patient had increased stainable iron in the marrow. Changes consistent with megaloblastic haematopoiesis were present in 8 marrows. These changes were notable in three and were judged to be moderate in five patients.

Two patients (aged 6 and 7 years) were clinically diagnosed to have splenic sequestration crises on the basis of severe anaemia (haemoglobin 2.6 and 1.4 $\mathrm{g} / \mathrm{dl}$ ) and noticeable sudden enlargement of the spleen. Bone marrow in both showed erythroid hyperplasia. Erythropoiesis was noticeably megaloblastic in one and no stainable iron was present in the marrow of the other.

Two boys were found to have glucose-6phosphate dehydrogenase deficiency; the bone marrows showed erythroid hyperplasia in both.

\section{Discussion}

Forty four per cent of children with sickle cell anaemia presenting with severe anaemia in our series were classified as having aplastic crises on the

Table 1 Clinical and bone marrow data in 14 children with sickle cell anaemia and marrow erythroid hypoplasia

\begin{tabular}{|c|c|c|c|c|c|}
\hline Patient & $\begin{array}{l}\text { Age } \\
\text { (yrs) }\end{array}$ & $\begin{array}{l}\text { Haemoglobin } \\
(\mathrm{g} / \mathrm{dl})\end{array}$ & $M: E$ ratio & $\begin{array}{l}\text { Marrow } \\
\text { iron }\end{array}$ & $\begin{array}{l}\text { Associated disease } \\
\text { or symptoms }\end{array}$ \\
\hline 1 & 4 & $3 \cdot 0$ & $70: 1$ & Absent & Tracheobronchitis \\
\hline 2 & 10 & $2 \cdot 1$ & $30: 1$ & Adequate & Malaria \\
\hline 3 & 11 & $2 \cdot 8$ & $36: 1$ & Absent & FUO \\
\hline 4 & $11 / 2$ & $3 \cdot 5$ & $5: 1$ & Reduced & Bronchopneumonia \\
\hline 5 & $41 / 2$ & $4 \cdot 6$ & $5: 1$ & Adequate & FUO \\
\hline 6 & 2 & $3 \cdot 6$ & $22: 1$ & Adequate & Septicaemia (Escherichia Coli) \\
\hline 7 & 7 & $2 \cdot 3$ & 16:1 & Reduced & Malaria \\
\hline 8 & 4 & $4 \cdot 0$ & 23:1 & Adequate & FUO \\
\hline 9 & $51 / 2$ & $2 \cdot 6$ & $6: 1$ & Adequate & Malaria \\
\hline 10 & 4 & $2 \cdot 1$ & $50: 1$ & Absent & - \\
\hline 11 & 9 & $2 \cdot 0$ & $50: 1$ & Absent & FUO \\
\hline 12 & 12 & $3 \cdot 3$ & $70: 1$ & Reduced & Typhoid fever (Salmonella typhi) \\
\hline 13 & 3 & $3 \cdot 8$ & $200: 1$ & Adequate & Acute osteitis/ósteomyelitis \\
\hline 14 & 4 & $3 \cdot 2$ & $90: 1$ & Adequate & Acute osteitis/ósteomyelitis \\
\hline
\end{tabular}

FUO = fever of unexplained origin; $M: E=$ myeloid:erythroid. 
Table 2 Clinical and bone marrow data in 17 children with sickle cell anaemia and marrow erythroid hyperplasia

\begin{tabular}{|c|c|c|c|c|c|c|}
\hline Patient & $\begin{array}{l}\text { Age } \\
\text { (yrs) }\end{array}$ & $\begin{array}{l}\text { Haemoglobin } \\
(\mathrm{g} / \mathrm{dl})\end{array}$ & $M: E$ ratio & $\begin{array}{l}\text { Marrow } \\
\text { iron }\end{array}$ & $\begin{array}{l}\text { Megaloblastic } \\
\text { changes }\end{array}$ & $\begin{array}{l}\text { Associated disease } \\
\text { or symptoms }\end{array}$ \\
\hline 15 & 3 & 4.9 & $1: 2$ & Adequate & Mild & Upper respiratory infection \\
\hline 16 & 9 & $4 \cdot 9$ & $1: 1 \cdot 5$ & Adequate & - & Painful crisis. G6PD deficiency \\
\hline 17 & 9 & $2 \cdot 6$ & $1: 2$ & Absent & Moderate & Lobar pneumonia \\
\hline 18 & 7 & $4 \cdot 4$ & $1: 1 \cdot 6$ & Adequate & Moderate & Chronic renal disease \\
\hline 19 & $31 / 2$ & $4 \cdot 5$ & $1: 2 \cdot 5$ & Reduced & - & Cholestatic jaundice \\
\hline 20) & 8 & $4 \cdot 3$ & $1: 1$ & Absent & Considerable & FUO \\
\hline 21 & $81 / 2$ & 4.9 & $1: 1 \cdot 6$ & Absent & - & FUO \\
\hline 22 & 6 & $2 \cdot 8$ & $1: 3 \cdot 5$ & Absent & - & Urinary tract infection \\
\hline 23 & 12 & $4 \cdot 4$ & $1: 1$ & Absent & Mild & Malaria, painful crisis \\
\hline 24 & 8 & $4 \cdot 1$ & $1: 3$ & Absent & - & Painful crisis \\
\hline 25 & 5 & $2 \cdot 8$ & $1: 1 \cdot 3$ & Absent & - & Urinary tract infection \\
\hline 26 & 6 & $4 \cdot 5$ & $1: 1$ & Absent & - & G6PD deficiency \\
\hline 27 & 10 & $3 \cdot 9$ & $1: 2$ & Reduced & - & FUO \\
\hline 28 & $1 \% 12$ & $3 \cdot 6$ & $1: 2 \cdot 5$ & Adequate & - & Acute otitis media \\
\hline 29 & $1^{11 / 12}$ & $4 \cdot 7$ & $1: 1$ & Absent & Considerable & Malaria \\
\hline 30 & 6 & $4 \cdot 6$ & $1: 1$ & Absent & Considerable & Malaria \\
\hline 31 & 6 & $2 \cdot 3$ & $1: 1$ & Increased & Moderate & - \\
\hline
\end{tabular}

$M: E=$ myeloid:erythroid: $F U O=$ fever of unexplained origin: $G 6 P D=$ glucose-6-phosphate dehydrogenase.

basis of noticeable reduction of erythroid precursors in the bone marrow and corresponding raised myeloid:erythroid ratios well in excess of $6: 1$. In sickle cell aplastic crisis there is a sudden, but transient, noticeable reduction of red cell turnover superimposed on the usual accelerated peripheral red cell destruction. Profound anaemia, often life threatening, develops within days. ${ }^{4}$ In our series, 7 of 14 patients diagnosed as having aplastic crises presented with a haemoglobin concentration of 3 $\mathrm{g} / \mathrm{dl}$, or less. Recovery from aplastic crisis is reported to take place within 10 to 14 days and this is heralded by a surge of nucleated red blood cells and noticeable reticulocytosis in the peripheral blood. ${ }^{3}$ The aetiology of this temporary failure of bone marrow in sickle cell anaemia is uncertain but a preceding or concomitant viral or bacterial infection has often been implicated as a precipitating or associated event ${ }^{4} 5$ and recently parvovirus infections have been specifically associated with aplastic crisis in this disease. ${ }^{67} \mathrm{~A}$ history of fever a few days before or on admission was obtained in 13 of the 14 patients diagnosed as having an aplastic crisis in the present series. Four of them had a fever of unknown origin which subsided spontaneously without a definite diagnosis having been made. Two had respiratory infections (bronchitis and bronchopneumonia) and another two had acute falciparum malarial infection documented by positive blood films. Bacterial pathogenes (Salmonella typhi and coliforms) were isolated from the blood in two patients and two others developed their aplastic crises while receiving treatment for clinically suspected osteomyelitis (Table 1).

Our experience and that of others ${ }^{3-6}$ strongly suggest that infections-viral, bacterial, or plasmodial-are generally the major precipitating events in the development of aplastic crises in sickle cell patients. Transient failure of erythropoiesis in these patients may result from some toxic or inhibitory effect of these infective agents on precursor red cells. This concept has been given added support by recent reports that sera containing parvolike viruses could inhibit haematopoietic progenitor colony formation in vitro. ${ }^{89}$ Where facilities are available (either electronmicroscopy or serology, or both) evidence of infection by these agents should now be sought to relate and define clearly their clinical role and importance to aplastic crises in populations where the frequency of sickle cell anaemia is high.

In 17 of the 33 children who presented with anaemic crises, bone marrow evaluation showed erythroid hyperplasia with myeloid:erythroid ratios ranging from $1: 1$ to $1: 3 \cdot 5$. Since the marrow of sickle cell patients manifests erythroid hyperplasia in the steady state its finding in an acute anaemic crisis is more difficult to interpret. Acute severe anaemia in the presence of marrow erythroid hyperplasia may suggest an increased rate of haemolysis superimposed on an already existing, chronic haemolytic anaemia-the so called hyperhaemolytic crisis. The frequency of a hyperhaemolytic crisis in sickle cell anaemia is, however, controversial. MacIver and Parker-Williams ${ }^{2}$ suggest that this type of crisis occurs rarely, if ever, in sickle cell anaemia and a similar view is expressed by Diggs. ${ }^{3}$ Mann et al, ${ }^{10}$ however, in a study of 16 episodes of acute anaemia necessitating urgent transfusion in 13 children with sickle cell anaemia presented evidence for increased haemolysis in five patients. This was based on findings of increased serum bilirubin concentrations, 
increased or maintained reticulocyte counts, and the presence of methaemalbuminaemia. That accelerated haemolysis is possible in sickle cell patients with glucose-6-phosphate dehydrogenase deficiency has also been well documented. ${ }^{11}$ On the other hand marrow erythroid hyperplasia in the presence of severe anaemia could represent the early recovery phase from aplastic crisis when delivery of red cells in any quantity into the circulation has not yet begun. ${ }^{2}$ Unfortunately reticulocyte counts were not available on all our patients on admission but 7 patients with marrow erythroid hyperplasia and severe anaemia in whom reticulocyte counts were available all had values between $2 \%$ and $6 \%$. Such relatively low reticulocyte counts in the presence of erythroid hyperplasia would strongly favour an early recovery phase from aplastic crisis rather than a hyperhaemolytic crisis. Three of the children with severe anaemia and erythroid hyperplasia had malaria parasitaemia and two others had glucose-6phosphate dehydrogenase deficiency. An accelerated destruction of red blood cells (hyperhaemolytic crisis) is conceivable under these circumstances.

Stainable iron was absent in the bone marrow of 14 of the 33 children with sickle cell anaemia and anaemic crisis. In five others iron stores were reduced. This strongly suggests iron deficiency anaemia as an associated factor in these children who presented with severe anaemia. It also suggests that iron depletion in general may be a relatively common deficiency in many children with sickle cell anaemia in west Africa. Obviously this has considerable clinical and health implications. Iron deficiency anaemia is generally not considered a medical problem in patients who have sickle cell disease. An increased gastrointestinal absorption of iron associated with haemolysis and iron provided by the red cells are thought to provide a sufficient source of iron. That this may not be entirely correct is supported by recent reports of well documented iron deficiency states in patients with sickle cell disease. ${ }^{12-15}$ Diet related geographical differences probably exist, however, in relation to the prevalence of iron deficiency in sickle cell patients. The studies by Rao and Sur from India, ${ }^{12}$ Oluboyede from Nigeria, ${ }^{13}$ and our data would indicate that iron deficiency is relatively common in sickle cell patients from countries where nutritional deficiencies are common. In contrast, Hussain et al ${ }^{16}$ have reported higher serum ferritin concentrations in children with sickle cell disease residing in Britain than in normal control children. Ferritin concentrations were so high in some children with sickle cell disease that ferritin concentration monitoring to prevent excessive iron accumulation was suggested.

The conclusive diagnosis of iron deficiency state should normally include estimation of plasma ferritin concentrations, transferrin saturation, and free erythrocyte protoporphyrin values. In many parts of the world, however, where facilities for the determination of the above are not readily available, examination of the bone marrow for haemosiderin remains the most simple, sensitive, and reliable method of judging the iron status. ${ }^{17}$

Megaloblastic marrow changes consistent with folate deficiency were present in 8 children whose marrows showed erythroid hyperplasia. Megaloblastic erythropoiesis was not documented in children who presented with hypoplastic marrows, possibly because the degree of suppression of erythropoiesis excluded marrow diagnosis of folate deficiency. Megaloblastic anaemia complicating sickle cell disease has been well documented in the published reports. ${ }^{18-21}$ Folate deficiency in sickle cell disease develops as the requirement for folic acid by an enhanced erythropoietic activity exceeds dietary intake. Previous dose response studies have suggested an abnormally high requirement for folic acid in sickle cell disease. ${ }^{20} 21$ In west Africa, where folate deficiency may be a common nutritional deficiency in children, ${ }^{22}$ the child with sickle cell disease is particularly at risk from developing megaloblastic anaemia superimposed on his chronic, haemolytic anaemia. Although children attending our sickle cell clinic were routinely prescribed a daily supplementary intake of folic acid ( 2.5 to $5 \mathrm{mg})$ and weekly chloroquine as prophylaxis against malaria, it is obvious from our data that a number of patients did not comply fully with these instructions.

Our evaluation of bone marrow in these children presenting with an anaemic crisis indicates a possible need for supplementary iron and folic acid in children with sickle cell disease living in the tropics where deficiencies of these two nutrients are prevalent. Supplementary iron may not be necessary, however, in those children who frequently require transfusion. We would suggest further that in centres where facilities are available, examination of the bone marrow should be undertaken in children with sickle cell anaemia who present with profound anaemia. This simple procedure allows easy assessment of erythroid activity and possible complicating iron and folate deficiencies.

\footnotetext{
References

' Singer K, Motulsky A, Wile SA. Aplastic crisis in sickle cell anaemia: study of its mechanism and its relationship to other types of haemolytic crisis. J Lab Clin Med 1950;35:721-36.

2 MacIver JE. Parker-Williams EJ. The aplastic crisis in sickle cell anaemia. Lancet 1961;i:1086-9.

3 Diggs LW. Sickle cell crises. Am J Clin Pathol 1965:44:1-19.

4 Leiken SL. Aplastic crisis in sickle cell disease. Am J Dis Child 1957;93:128-39.
} 
5 Chernoff AI, Josephson AM. Acute erythroblastopemia in sickle cell anaemia and infectious mononucleosis. Am J Dis Child 1951;82:310-22.

- Sergeant GR, Topley JM, Mason K, et al. Outbreak of aplastic crises in sickle cell anaemia associated with parvovirus-like agent. Lancet 1981;ii:595-7.

7 Pattison JR, Jones, SE, Hodgson J, et al. Parvovirus infections and hypoplastic crisis in sickle cell anaemia. Lancet 1981 ;i: 664-5.

${ }^{8}$ Mortimer PP, Humphries RK, Moore JG, Purcell RH, Young NS. A human parvovirus-like virus inhibits haematopoietic colony formation in vitro. Nature 1983;302:426-9.

9 Duncan JR, Potter CG, Cappellini MD, Kurtz JB, Anderson NJ, Weatherall DJ. Aplastic crisis due to parvovirus infection in pyruvate kinase deficiency. Lancet 1983;ii:14-6.

${ }^{10}$ Mann JR, Cotter KP, Walker RA, Bird WG, Stuart J. Anaemic crisis in sickle cell disease. J Clin Pathol 1975;28:431-44.

11 Smits HL, Oski FA, Brody J. The hemolytic crisis of sickle cell disease: the role of glucose-6-phosphate dehydrogenase deficiency. J Pediatr 1969;74:544-51.

12 Rao NJ, Sur AM. Iron deficiency in sickle cell anaemia. Acta Paediatr Scand 1980;69:337-40.

${ }^{13}$ Oluboyede OA, Olufunmike A, Ajayi A, Adeyokunna A. Iron studies in patients with sickle cell disease. Afr J Med Med Sci 1981;10:1-7.
14 Vishinsky E, Kleman K, Embury S, Lubin B. The diagnosis of iron deficiency in sickle cell disease. Blood 1981;58:963-8.

15 Haddy T, Castro O. Overt iron deficiency in sickle cell disease. Arch Intern Med 1982;142:1621-4.

${ }^{16}$ Hussain AM, Davies LR, Lanlicht M, Hoffbrand AV. Value of serum ferritin estimation in sickle cell anaemia. Arch Dis Child 1978;53:319-21.

17 Fleming AF. Iron deficiency in the tropics. Clin Haematol 1982;11:358-82.

${ }^{18}$ MacIver JE, Went LN. Sickle cell anaemia complicated by megalo-blastic anaemia of infancy. $\mathrm{Br}$ Med J 1980;i:775-9.

19 Watson-Williams EJ. Folic acid deficiency and sickle cell anaemia. East Afr Med J 1962;39:213-21.

20 Lindenbaum J, Klipstein FA. Folic acid deficiency in sickle cell anaemia. $N$ Engl J Med 1963;268:875-82.

21 Alperin JB. Folic acid deficiency complicating sickle cell anaemia. Arch Intern Med 1967;120:298-306.

22 Fleming AF, Werblinska B. Anaemia in childhood in the Guinea Savana of Nigeria. Annals of Tropical Paediatrics 1982;2:161-73.

Correspondence to Professor F K Nkrumah, Department of Paediatrics and Child Health, Medical School, University of Zimbabwe, Harare, Zimbabwe

Received 17 February 1984 